\title{
Identification of breast cancer molecular targets interacting with molecules present in the fruits of Antidesma bunius: In silico network pharmacology - based analysis
}

\section{Identificación de dianas moleculares del cáncer de mama que interactúan con moléculas presentes en los frutos de Antidesma bunius: análisis basado en farmacología de red in silico}

\author{
Funing $\mathrm{MA}^{1}$, Jorge Luis GUTIERREZ-PAJARES ${ }^{2}$, Dongmei $\mathrm{HUANG}^{1}$, Yi XU ${ }^{1}$, Bin $\mathrm{WU}^{1}$ and Shun \\ $\mathrm{SONG}^{l}$
}

${ }^{1}$ Haikou Experimental Station, Chinese Academy of Tropical Agricultural Sciences, Hainan 571101, China ${ }^{2}$ Le Cordon Bleu University, Peru.

\begin{abstract}
The fruit of Antidesma bunius has both medicinal and edible properties. In previous studies, the fruit extract of A. bunius showed anti-proliferation activity on breast cancer cells, but its functional components and anti-tumor mechanism are still unclear. In this research, the main active components of A. bunius fruits (detected by UHPLC-MS/MS) and the corresponding targets were analyzed by network pharmacology method, and its interactions were verified by molecular docking to explore the possible tumor suppressor mechanisms. A total of 24 active chemical components were screened from fruits extract of $A$. bunius, and 44 targets genes were intersected with breast cancer, among them, AKT1, ESR1, EGFR, EP300, ERBB2 and AR were the top core targets. The GO enrichment of target genes mainly involved processes of cellular lipid metabolism, response to hormones, tube development, and KEGG pathway analysis centers in cancer pathways present in breast, pancreatic and non-small cell lung cancer. The flavonoids in the fruits of A. bunius showed strong binding to the core targets by molecular docking analysis. These results strongly suggest that the flavonoids in the fruit of $A$. bunius can inhibit proliferation of breast cancer through multiple targets, mainly by ERK and PI3K-AKT pathways.
\end{abstract}

Keywords: Antidesma bunius, breast cancer, network pharmacology, target of action, molecular docking.

\section{RESUMEN}

El fruto de Antidesma bunius tiene propiedades medicinales y comestibles. En estudios anteriores, el extracto de fruta de $A$. bunius mostró actividad antiproliferativa en las células de cáncer de mama, pero sus componentes funcionales y mecanismo antitumoral aún no están claros. En esta investigación se analizaron los principales componentes activos de los frutos de $A$. bunius (detectados por UHPLC-MS / MS) y las dianas correspondientes mediante el método de farmacología en red, y se

Funing MA. ORCID: https://orcid.org/0000-0002-6184-6814 email: funingma@163.com

Jorge Luis Gutierrez-Pajares. ORCID: https://orcid.org/0000-0002-3573-0754 email: jorge.gutierrez@ulcb.edu.pe

Dongmei HUANG. ORCID: https://orcid.org/0000-0002-5412-4063 email: snowdream1105@163.com

Yi XU. ORCID: https://orcid.org/0000-0003-4228-8519 email: lukydog163@163.com

Bin WU. ORCID: https://orcid.org/0000-0001-5169-2674 email: wubin520327@163.com

Shun SONG. ORCID: https://orcid.org/0000-0002-4176-8978 email: sss1984006@163.com 
verificaron sus interacciones mediante acoplamiento molecular para explorar los posibles mecanismos supresores de tumores. Se seleccionaron un total de 24 componentes químicos activos del extracto de frutas de A. bunius, y 44 genes diana se cruzaron con el cáncer de mama, entre ellos, AKT1, ESR1, EGFR, EP300, ERBB2 y AR fueron los principales objetivos principales. de los genes diana involucraban principalmente procesos de metabolismo de lípidos celulares, respuesta a hormonas, desarrollo de tubos y centros de análisis de la vía KEGG en las vías del cáncer presentes en el cáncer de mama, páncreas y pulmón de células no pequeñas. Los flavonoides en los frutos de $A$. bunius mostraron fuertes unión a los objetivos centrales mediante análisis de acoplamiento molecular. Estos resultados sugieren fuertemente que los flavonoides en la fruta de $A$. bunius pueden inhibir la proliferación del cáncer de mama a través de múltiples dianas, principalmente por las vías ERK y PI3K-AKT.

Palabras clave: Antidesma bunius, cáncer de mama, farmacología de la red, objetivo de la acción, acoplamiento molecular.

\section{INTRODUCTION}

$A^{\prime}$ ntidesma bunius, also known as five-flavored leaf, is a sour tree in China, belonging to the Euphorbiaceae family (B. Li \& Hoffmann, 2008). A. bunius plants are native to Southeast Asia. Currently, its habitat is mainly distributed in Jiangxi, Hunan, Guangdong, Guangxi, Fujian, Guizhou, Yunnan, Tibet and Hainan in China and in tropical and subtropical regions of Asia, Africa and America. There are about 170 species of Antidesma. Among them, A. bunius, A. ghaesembilla, A. montanous and A. pseudomicrophyllum are considered to have medicinal properties (Wei, Gao, 2015).

After the fruit of $A$. bunius matures, the color also changes from red to dark purple. The taste is sweet and sour, and can be eaten raw, or used to prepare jam, fruit juice and fruit wine products. In traditional Chinese medicine the roots, leaves and fruits of $A$. bunius are used as medicine: to relieve coughing and diarrhea, and promoting blood circulation, as well as improving sores and malignant syphilis (Shanghai Science and Technology Press, 1999). Traditionally, an $A$. bunius tree planted in the Ming Dynasty in Guangdong is used to formulate medicinal materials to treat various diseases of the villagers (Dai, 2016).

It has been reported that the fruit of $A$. bunius contains several important molecules for our health, such as organic acids, vitamins, minerals, anthocyanins, flavonoids and phenolic acids ( $\mathrm{J} . \mathrm{Li}, 1995)$. Breast cancer is the malignant disease tumor with the highest incidence in women. Our previous study found that the ethanol extract of the fruit of $A$. bunius and the ethyl acetate extract of the leaves of $A$. mentounes inhibit breast cancer cell proliferation and invasion (Krongyut \& Sutthanut, 2019; Zhaohui, 2011). In the present study, the main active components in the fruit of A. bunius were used to identify key targets to inhibit breast cancer growth through network pharmacology and molecular docking methods.

\section{Materials AND MethodS}

\section{Screening of active components and target prediction of} A. bunius fruit extract

Compounds of $A$. bunius fruit extract were obtained by UHPLC-MS/MS and were sorted by peak area, and the top 100 chemical components with MS2 score $>0.9$ were selected using PubChem (https://pubchem.ncbi.nlm.nih.gov/). The database queried its Simplified Molecular Input Line Entry
System (SMILES) chemical formula, entered the stitch (http://stitch.embl.de/cgi/) database in groups, and screened the active ingredients with homology coexpression $>0.5$, and developed a network map of the active ingredients of $A$. bunius. To predict the target of the compounds, the SEA (http://sea.bkslab.org/) and Chemmapper (http://lilabecust.cn/chemmapper/) database were used. Then the Uniprot (www.uniprot.org/) database was used to transform the target name into a standard human gene.

\section{Breast cancer related targets prediction and protein interaction network (PPI) construction}

The keyword "Breast cancer" was searched in NCBI-gene (https://www.ncbi.nlm.nih.gov/gene), (https://www.genecards.org/) and Uniprot (https://www.uniprot.org). Breast cancer (BC)-related targets were obtained and combined by setting the species as human "Homo sapiens" and with screening threshold score $>$ 10 in Genecards.

The intersection targets of $A$. bunius active ingredients and $\mathrm{BC}$ were solved by Tbtools software, and the results were applied to construct the protein-protein interaction (PPI) with common targets of A. bunius and $\mathrm{BC}$, by setting the lowest interaction threshold "highest confidence" to 0.9 in the String database (https://string-db.org/). The CytoHubba plug-in of Cytoscape software was used to rank network data nodes and screen out key target proteins.

\section{GO biological function analysis, KEGG pathway enrichment \\ The intersection targets of active ingredients of $A$. bunius} and $\mathrm{BC}$ were loaded into Webgestalt (http://www.webgestalt.org/) database for GO function enrichment $(\mathrm{P} \leq 0.01)$ and $\mathrm{KEGG}$ pathway enrichment to analyze the main pathways involved in inhibiting $\mathrm{BC}$.

\section{A. bunius fruit components-Disease Target-Pathway Network Construction}

The key active ingredients of $A$. bunius fruit, the intersection targets of active ingredients of $A$. bunius and BC and the top 10 KEGG pathways interactions were analyzed by Cytoscape software, and use Merge function to construct a network diagram.

\section{Molecular docking for target verification}

The protein crystal structure of the key target and the 3D structure of the key active ingredients were downloaded from Uniprot (www.uniprot.org/), the PDB

https://doi.org/10.46908/tayacaja.v4i2.171 dol pág. 48 
ISSNe: 2617-9156

(https://www.rcsb.org/) and the Pubchem websites (https://pubchem.ncbi.nlm.nih.gov/). AutoDock Vina (http://autodock.scripps.edu/) were used to molecularly dock the key targets with higher Degree values active ingredients, and finally Pymol (https://pymol .org/) software was used to visualize the molecular docking view.

\section{Results}

Key active compounds and targets of A.bunius

The 100 chemical components of $A$. bunius were grouped into the Stitch (http://stitch.embl.de/cgi/) website, and the compounds with a score $>0.5$ were combined and screened as active ingredients. A total of 24 active ingredients were obtained as shown in Table 1. Among them, phenylpropane and polyketone compounds accounted for the highest proportions, with a total of 11 ingredients, followed by benzoic acid esters with 6 types, and organic acids and their derivatives with 4 types.

Table 1.

Active compounds of $A$. bunius. $\mathrm{mz}=$ mass-to-charge ratio, $\mathrm{OB}=$ oral bioavailability, $\mathrm{MOL}$ ID $=$ Molecular identification.

\begin{tabular}{|c|c|c|c|c|c|c|}
\hline No. & Molecule name & $\mathbf{m z}$ & Compound type & $\mathrm{OB} / \%$ & MOL ID & Type \\
\hline 1 & $\begin{array}{l}\text { 4-hydroxycinnamic } \\
\text { acid }\end{array}$ & 163.0396 & Phenylpropane and polyketone compounds & 43.29 & MOL000771 & - \\
\hline 2 & Gallic acid & 169.0134 & Parabens & 31.69 & MOL000513 & - \\
\hline 3 & luteolin-7-O-g. & 447.0927 & Phenylpropane and polyketone compounds & 7.29 & MOL000009 & - \\
\hline 4 & 3-hydroxybenzo. & 137.0235 & Parabens & 22.19 & MOL011957 & - \\
\hline 5 & fumarate & 115.0031 & Organic acid & 29.03 & MOL004211 & - \\
\hline 6 & choline & 104.1071 & Organic nitrogen & 0.47 & MOL000394 & + \\
\hline 7 & cosmosiin & 431.0987 & Phenylpropane and polyketone compounds & 9.68 & MOL000007 & + \\
\hline 8 & pyrogallol & 125.0236 & Parabens & 22.98 & MOL000106 & - \\
\hline 9 & Vanillic acid & 167.0345 & Parabens & 35.47 & MOL000114 & - \\
\hline 10 & Aspirin & 179.0344 & Parabens & & & - \\
\hline 11 & benzoic acid & 121.0287 & Parabens & 30.15 & MOL000103 & - \\
\hline 12 & malonate & 103.0028 & Organic acid & 21.69 & MOL001738 & - \\
\hline 13 & succinic semia. & 101.0236 & Lipids and lipid-like molecules & & & - \\
\hline 14 & naringenin & 271.0606 & Phenylpropane and polyketone compounds & 43.29 & MOL000771 & - \\
\hline 15 & quercitrin & 447.0926 & Phenylpropane and polyketone compounds & 4.04 & MOL000701 & - \\
\hline 16 & biochanin $\mathrm{A}$ & 285.0754 & Phenylpropane and polyketone compounds & 25.21 & MOL000510 & - \\
\hline 17 & Diosmetin & 301.0697 & Phenylpropane and polyketone compounds & 31.14 & MOL002881 & + \\
\hline 18 & gamma-amin.yri. & 104.0708 & Organic acids and their derivatives & 24.09 & MOL000388 & + \\
\hline 19 & daidzin & 417.1153 & Phenylpropane and polyketone compounds & 14.32 & MOL009720 & + \\
\hline 20 & Luteolin & 285.0401 & Phenylpropane and polyketone compounds & 36.16 & MOL000006 & - \\
\hline 21 & Kaempferol & 287.055 & Phenylpropane and polyketone compounds & 41.88 & MOL000422 & + \\
\hline 22 & Adenine & 136.0616 & Organic heterocyclic compound & 62.81 & MOL001788 & - \\
\hline 23 & betaine & 118.0863 & Organic acids and their derivatives & 40.92 & MOL000430 & + \\
\hline 24 & genistein & 269.0451 & Phenylpropane and polyketone compounds & 17.93 & MOL000481 & - \\
\hline
\end{tabular}

From the active ingredient relationship diagram analyzed on the Stitch website, it can be seen that flavonoids (narigenin, kaempferol, luteolin and genistein) and organic acids (gallic acid, vanillic acid, benzoic acid, coumaric acid) are the ingredients centered with more interactions (Figure 1). At the center of the network, the main targets are ESR2 and ESR1. Aspirin, choline and adenine are connected to the center through PTGS1, PTGS2, and BCHE targets. 


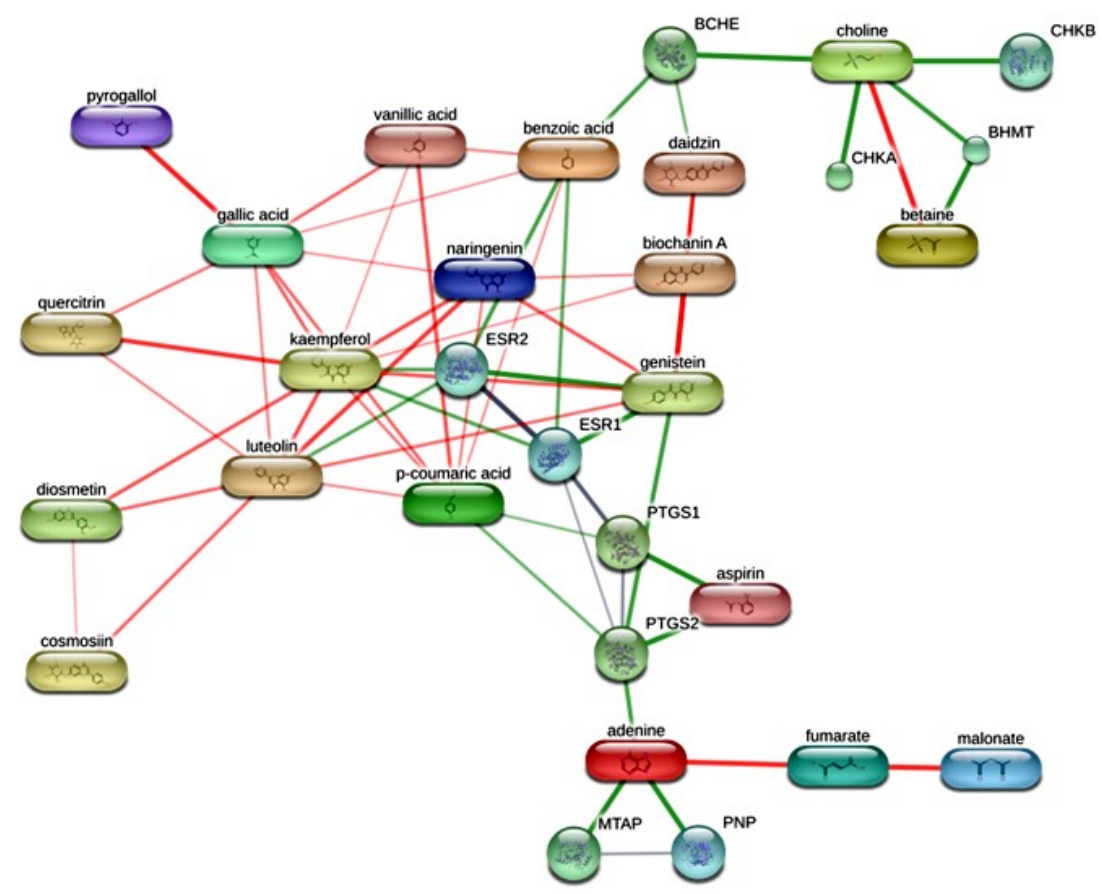

Figure 1.

Target network of effective chemical components of $A$. bunius fruit. Circles and rounded rectangles represent BC molecular targets and A. bunius molecules, respectively. Small nodes: protein of unknown 3D structure, large nodes: some 3D structure is known or predicted; colored nodes: query proteins and first shell of interactors. The thickness of the connecting lines indicates the level of confidence between the connected molecules.

\section{Common targets for breast cancer and compounds}

The 24 key compounds of $A$. bunius were queried in the SEA database to obtain 261 target points, and 538 target points were obtained from the Chemmapper database. After integrating the targets of the Stitch database a total of 792 targets for the fruit components of $A$. bunius were obtained.

By searching the NCBI-gene database, 4696 potential targets related to breast cancer were retrieved. The Genecards database (score $>10$ ) screened 1670 targets related to breast cancer and 1881 related targets in the Uniprot database. Using Tbtools to draw a Venn diagram with the results of the above three databases and the compound targets of $A$. bunius (Figure 2), 44 target genes of $A$. bunius in breast cancer were obtained (Table 2), including RAC-aserine/threonine RAC-alpha serine/threonine-protein kinase (AKT1), estrogen receptor (ESR1), epidermal growth factor receptor (EGFR), histone acetyltransferase (Histone acetyltransferase p300, EP300), receptor tyrosine-protein kinase erbB-2 (Receptor tyrosine-protein kinase erbB-2, ERBB2), androgen receptor (Androgen Receptor, AR) and other enzymes and factors (Table 2).

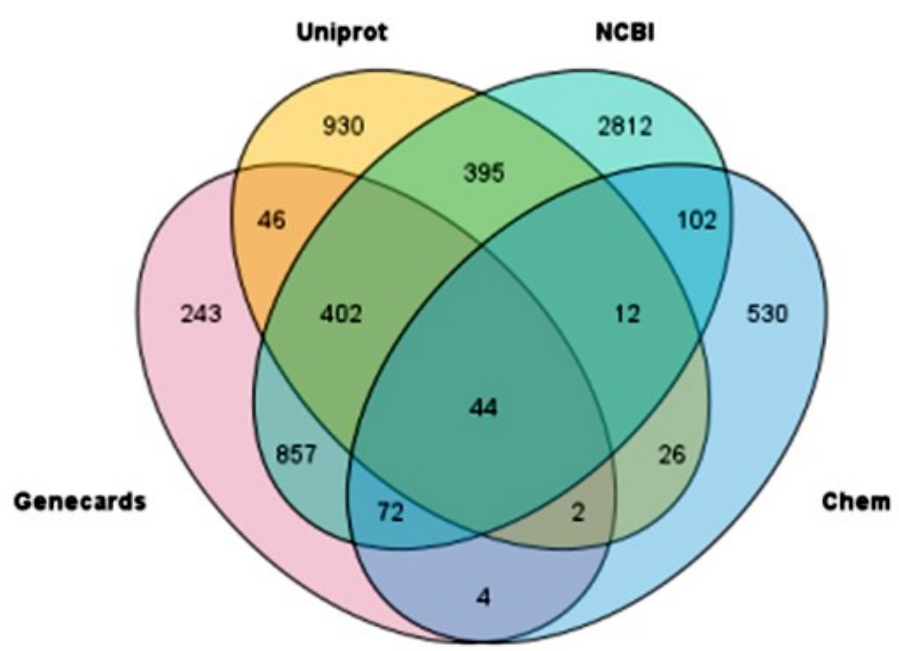

Figure 2.

Wayne map of the targets related to breast cancer. This map was obtained by TBtools software using shared targets of breast cancer from NCBI, Genecards and Uniprot database with the compound targets of A. bunius fruits. 
Table 2.

ISSNe: 2617-9156

Common targets of effective chemical components of $A$. bunius in breast cancer.

\begin{tabular}{|c|c|c|c|c|c|c|c|}
\hline No. & Target & Name & Family & No. & Target & Name & Family \\
\hline 1 & AKT1 & $\begin{array}{l}\text { RAC-alpha } \\
\text { serine/threonine- } \\
\text { protein kinase }\end{array}$ & Kinase & 23 & ABCG2 & $\begin{array}{c}\text { Broad substrate specificity } \\
\text { ATP-binding cassette } \\
\text { transporter ABCG2 }\end{array}$ & Transporter \\
\hline 2 & ESR1 & Estrogen receptor & $\begin{array}{l}\text { Nuclear } \\
\text { receptor }\end{array}$ & 24 & IDH1 & $\begin{array}{l}\text { Isocitrate dehydrogenase } \\
\text { [NADP] cytoplasmic }\end{array}$ & Enzyme \\
\hline 3 & EGFR & $\begin{array}{l}\text { Epidermal growth } \\
\text { factor receptor }\end{array}$ & Kinase & 25 & HDAC5 & Histone deacetylase 5 & Epigenetic \\
\hline 4 & EP300 & $\begin{array}{l}\text { Histone } \\
\text { acetyltransferase p300 }\end{array}$ & Epigenetic & 26 & NOS2 & $\begin{array}{l}\text { Nitric oxide synthase, } \\
\text { inducible }\end{array}$ & Enzyme \\
\hline 5 & ERBB2 & $\begin{array}{l}\text { Receptor tyrosine- } \\
\text { protein kinase erbB-2 }\end{array}$ & Kinase & 27 & FABP4 & $\begin{array}{l}\text { Fatty acid-binding protein, } \\
\text { adipocyte }\end{array}$ & \\
\hline 6 & $\mathrm{AR}$ & Androgen receptor & $\begin{array}{l}\text { Nuclear } \\
\text { receptor }\end{array}$ & 28 & KLF5 & Krueppel-like factor 5 & $\begin{array}{l}\text { Transcription } \\
\text { factor }\end{array}$ \\
\hline 7 & PPARG & $\begin{array}{l}\text { Peroxisome } \\
\text { proliferator-activated } \\
\text { receptor gamma }\end{array}$ & $\begin{array}{l}\text { Nuclear } \\
\text { receptor }\end{array}$ & 29 & PIN1 & $\begin{array}{l}\text { Peptidyl-prolyl cis-trans } \\
\text { isomerase NIMA- } \\
\text { interacting } 1\end{array}$ & Enzyme \\
\hline 8 & HDAC1 & Histone deacetylase 1 & Epigenetic & 30 & RET & $\begin{array}{l}\text { Proto-oncogene tyrosine- } \\
\text { protein kinase receptor Ret }\end{array}$ & Kinase \\
\hline 9 & $\mathrm{CDK} 4$ & $\begin{array}{l}\text { Cyclin-dependent } \\
\text { kinase } 4\end{array}$ & Kinase & 31 & DPP4 & Dipeptidyl peptidase 4 & Enzyme \\
\hline 10 & SMAD3 & $\begin{array}{l}\text { Mothers against } \\
\text { decapentaplegic } \\
\text { homolog } 3\end{array}$ & $\begin{array}{l}\text { Transcription } \\
\text { factor }\end{array}$ & 32 & EDNRA & Endothelin-1 receptor & $\begin{array}{l}\text { G protein } \\
\text { coupled receptor }\end{array}$ \\
\hline 11 & PARP1 & $\begin{array}{l}\text { Poly [ADP-ribose] } \\
\text { polymerase } 1\end{array}$ & Enzyme & 33 & AURKB & Aurora kinase B & Kinase \\
\hline 12 & RHOA & $\begin{array}{l}\text { Transforming protein } \\
\text { RhoA }\end{array}$ & Enzyme & 34 & KDM5B & $\begin{array}{l}\text { Lysine-specific } \\
\text { demethylase } 5 \mathrm{~B}\end{array}$ & $\begin{array}{l}\text { Transcription } \\
\text { factor; } \\
\text { epigenetic }\end{array}$ \\
\hline 13 & $\mathrm{CDK} 2$ & $\begin{array}{l}\text { Cyclin-dependent } \\
\text { kinase } 2\end{array}$ & Kinase & 35 & BRAF & $\begin{array}{l}\text { Serine/threonine-protein } \\
\text { kinase B-raf }\end{array}$ & Kinase \\
\hline 14 & GSK3B & $\begin{array}{l}\text { Glycogen synthase } \\
\text { kinase-3 beta }\end{array}$ & Kinase & 36 & INSR & Insulin receptor & Kinase \\
\hline 15 & STAT1 & $\begin{array}{l}\text { Signal transducer and } \\
\text { activator of } \\
\text { transcription 1- } \\
\text { alpha/beta }\end{array}$ & $\begin{array}{l}\text { Transcription } \\
\text { factor }\end{array}$ & 37 & HMGB1 & $\begin{array}{l}\text { High mobility group } \\
\text { protein B1 }\end{array}$ & $\begin{array}{l}\text { Transcription } \\
\text { factor }\end{array}$ \\
\hline 16 & NOS3 & $\begin{array}{l}\text { Nitric oxide synthase, } \\
\text { endothelial }\end{array}$ & Enzyme & 38 & FOLH1 & $\begin{array}{c}\text { Glutamate } \\
\text { carboxypeptidase } 2\end{array}$ & Enzyme \\
\hline 17 & PTPRC & $\begin{array}{l}\text { Receptor-type tyrosine- } \\
\text { protein phosphatase C }\end{array}$ & Enzyme & 39 & RARB & Retinoic acid receptor beta & $\begin{array}{l}\text { Nuclear } \\
\text { receptor }\end{array}$ \\
\hline 18 & AURKA & Aurora kinase A & Kinase & 40 & SDHD & $\begin{array}{l}\text { Succinate dehydrogenase } \\
\text { [ubiquinone] cytochrome b } \\
\text { small subunit, } \\
\text { mitochondrial }\end{array}$ & Enzyme \\
\hline 19 & PRKACA & $\begin{array}{c}\text { Protein kinase } \mathrm{C} \text { alpha } \\
\text { type }\end{array}$ & Kinase & 41 & GRM1 & $\begin{array}{l}\text { Metabotropic glutamate } \\
\text { receptor } 1\end{array}$ & $\begin{array}{l}\text { G protein } \\
\text { coupled receptor }\end{array}$ \\
\hline 20 & ESR2 & Estrogen receptor beta & $\begin{array}{l}\text { Nuclear } \\
\text { receptor }\end{array}$ & 42 & EPHB4 & Ephrin type-B receptor 4 & Kinase \\
\hline 21 & TOP1 & DNA topoisomerase 1 & Enzyme & 43 & CA2 & Carbonic anhydrase 2 & Enzyme \\
\hline 22 & HDAC6 & Histone deacetylase 6 & Epigenetic & 44 & LEPREL1 & Prolyl 3-hydroxylase 2 & Enzyme \\
\hline
\end{tabular}




\section{Protein interaction network (PPI)}

Import 44 common targets into the String database to obtain protein interaction information (Figure 3). Cytoscape's cytoHubbs was used to select the top 10 targets as AKT1, ESR1, EGFR, EP300, ERBB2, AR, PPARG, HDAC1, SMAD3, CDK4. The Degree and Closeness values of the first 6 targets of Degree are shown in Table 3.

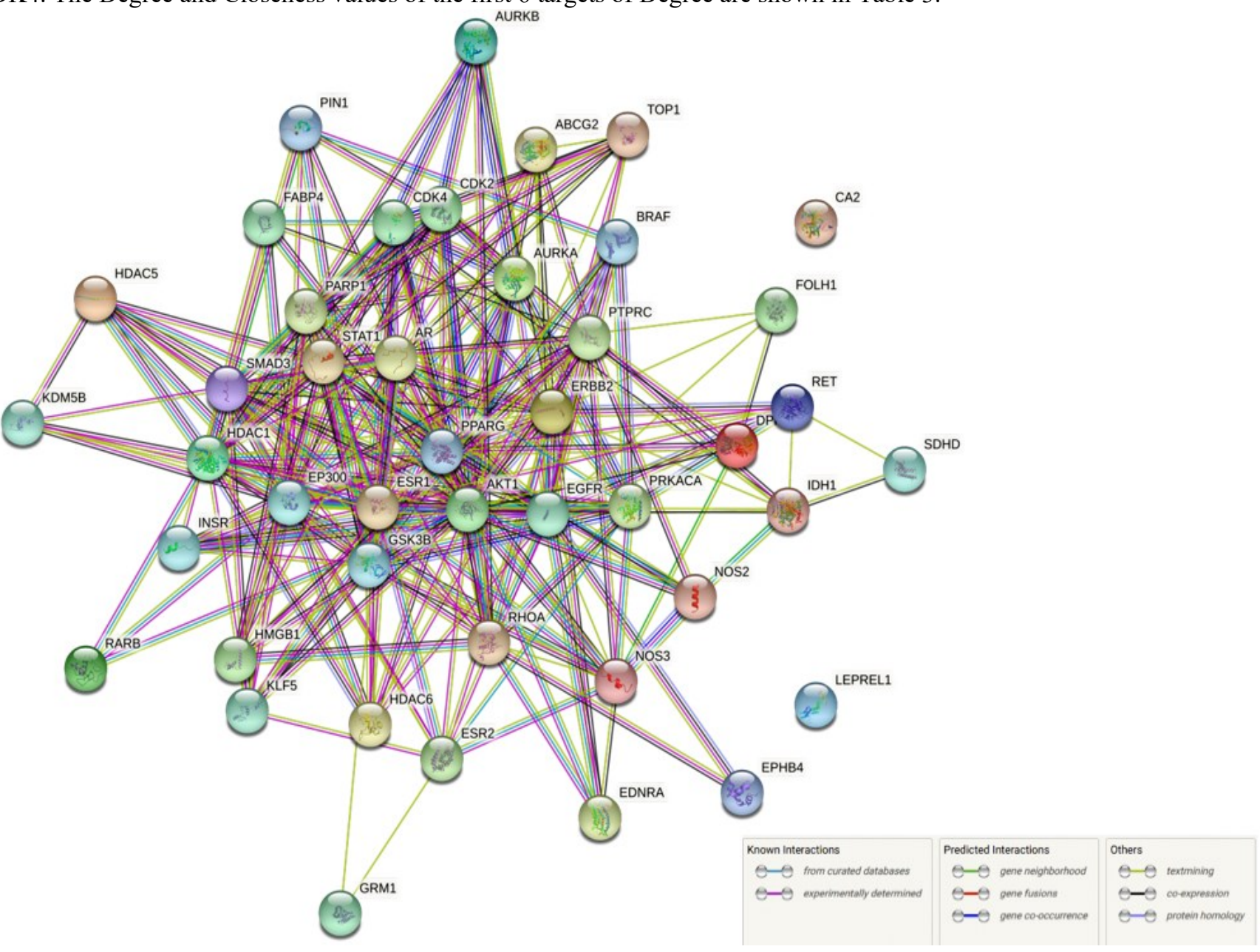

Figure 3.

PPI network of targets of $A$. bunius fruit effective chemical components in breast cancer context.

Table 3. Degree values of core targets.

\begin{tabular}{lllllll}
\hline No. & Target & Degree & Protein & Protein name & Protein receptor & Closeness \\
\hline 1 & AKT1 & 32 & P31749 & RAC-alpha serine/threonine-protein kinase & 6 CCY & 37 \\
2 & ESR1 & 24 & P03372 & Estrogen receptor & 3 OS8 & 33 \\
3 & EGFR & 24 & P00533 & Epidermal growth factor receptor & 5 UGA & 33 \\
4 & EP300 & 23 & Q09472 & Histone acetyltransferase p300 & $5 X X H$ & 32.3 \\
5 & ERBB2 & 23 & P04626 & Receptor tyrosine-protein kinase erbB-2 & 3 PPO & 32.5 \\
6 & AR & 20 & P10275 & Androgen receptor & $4 O E A$ & 30.3 \\
\hline
\end{tabular}

\section{GO enrichment and KEGG pathway}

The key targets were enriched and analyzed on the Metascape website, and GO was enriched in biological processes such as cellular response lipid, response to hormone, and tube development. The KEGG pathway was mainly enriched in pancreatic cancer, no-small cell lung cancer, endocrine resistance, prostate cancer, hypoxia inducible factor (HIF-1) and Fork head transcription factor $\mathrm{O}$ (FoxO) signaling pathway, breast cancer, gastric cancer, pathways in cancer, human papillomavirus infection and other pathways. 


\section{GO enrichment}

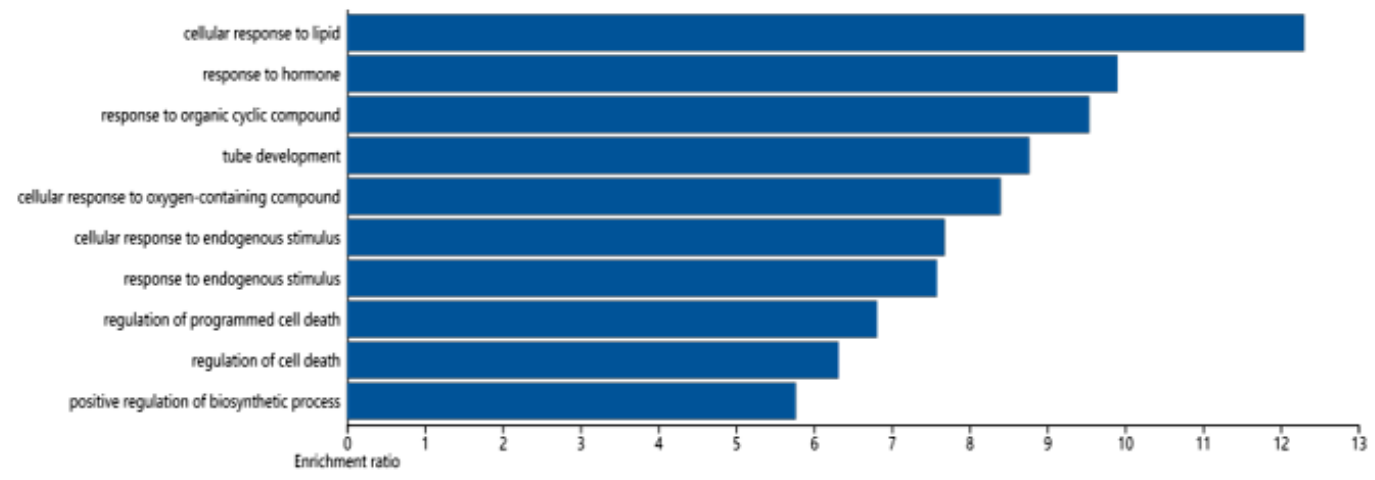

KEGG pathways

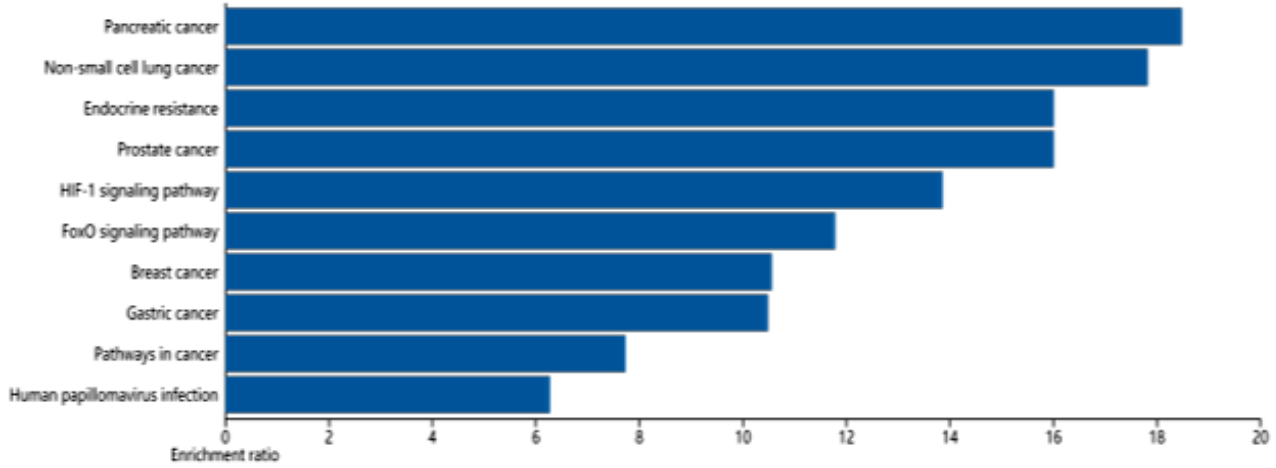

Figure 4.

Diagram of GO enrichment and KEGG pathway of $A$. bunius inhibition of BC.

KEGG network diagram of active ingredients in $A$. bunius interacting with breast cancer targets

Cytoscape software was used to design a network diagram of $A$. bunius active compounds-key targets-KEGG pathway (Figure 5). The active compounds of $A$. bunius ranked in the top 10 according to degree are kaempferol, luteolin, p-coumaric acid, gallic acid, genistein Genistein, benzoic acid, narigenin, choline, vanillic acid and quercetin. From this pathway network diagram, it can be found that the active components of $A$. bunius interact with a variety of cancer pathways, such as estrogen, thyroid hormone and HIF-1 signaling pathways. In addition to breast cancer, the active ingredients of $A$. bunius interacted with other types of cancer like prostate and pancreatic cancers

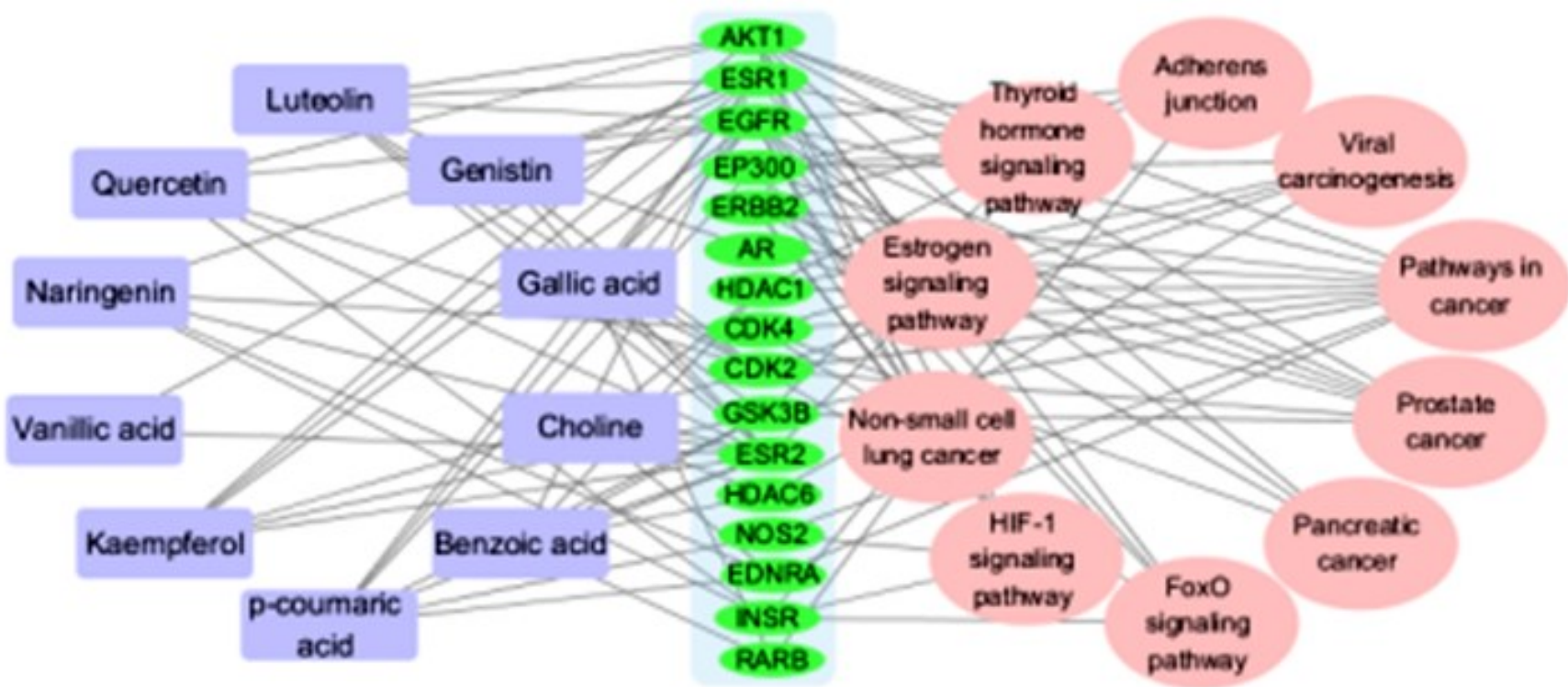

Figure 5.

Network of A. bunius active compounds - Breast cancer molecular key targets - KEGG pathways. 
From the breast cancer KEGG pathway diagram (Figure 6), it can be seen that 4 of the 6 core targets (ER, HER, EGFR, AKT, marked in red) enrich this pathway. For luminal type A breast cancer, the estrogen receptor (ER) that acts on the cytoplasm or nucleus could affect the cell cycle regulator CCND1, thereby contributing to cell proliferation. For other types of breast cancer, the active ingredients of $A$. bunius could affect the cell cycle and block the proliferation of tumor cells by acting on the receptors EGFR, HER, ERK, and PI3K-AKT on the cell membrane.

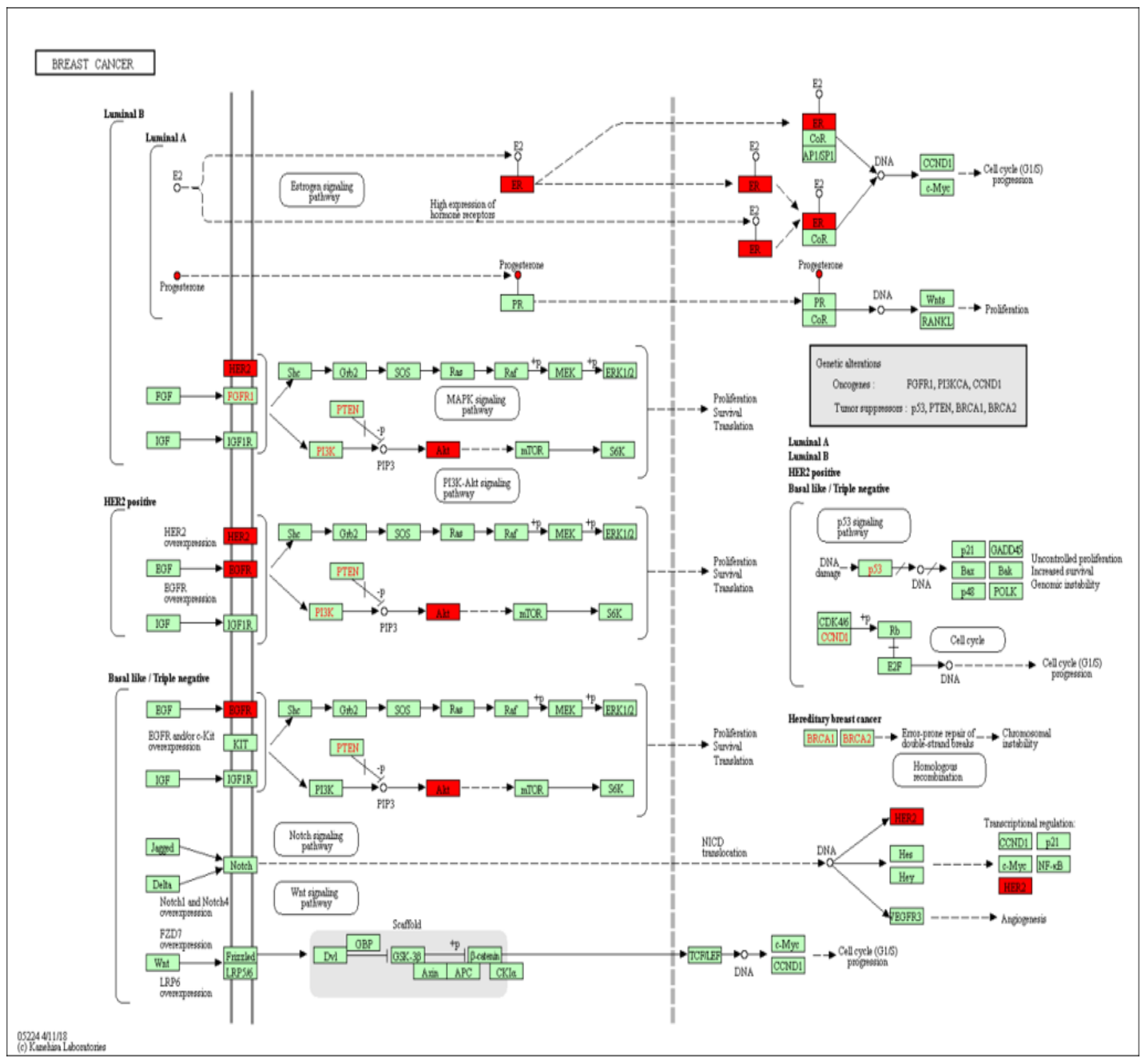

Figure 6.

Diagram of breast cancer KEGG pathway.

\section{Molecular docking}

The top 10 degrees of active ingredients of A. bunius, one diflavonoid (amentoflavone) and one flavonoid glycoside (luteolin 7-galactoside), and 6 core target proteins: AKT1 (6CCY), ESR1 (3OS8), EGFR (5UGA), EP300 (5XXH), ERBB2 (3PPO), AR (40EA) were selected for molecular docking. The molecular docking binding energy is based on $-7 \mathrm{~kJ} \cdot \mathrm{mol}-1$ as the affinity threshold, and those smaller than this value are considered to have better binding properties (Cai et al., 2021). From the docking binding energy score, it can be seen that the score values of kaempferol, luteolin, genistein, naringenin binding to AKT1, ESR1, ERBB2, and AR are all less than -7kJ·mol-1 (Figure 7). The score values of coumaric acid, gallic acid, benzoic acid and vanillic acid are in the range of -7 to -4 , and the score value of choline is greater than $-4 \mathrm{~kJ} \cdot \mathrm{mol}-1$. Although amentoflavone and luteolin 7-galactoside are not among the key compounds of A. bunius, the score values of the binding of amentoflavone and luteolin 7-galactoside with the 6 core target proteins are all less than $-7 \mathrm{~kJ} \cdot \mathrm{mol}-1$. 
ISSNe: 2617-9156

\begin{tabular}{c|c|c|c|c|c||c|c|} 
Kaempfeol & -7.4 & -8.2 & -7.7 & -6.8 & -8.9 & -7.2 & -10 \\
Luteolin & -7.7 & -8.6 & -7.7 & -6.4 & -9.5 & -8 & -8 \\
Coumaric acid & -5.4 & -5.9 & -6 & -4.8 & -6.1 & -6.3 & -6 \\
Gallic acid & -5.5 & -5.7 & -5.5 & -4.6 & -6.2 & -6.1 & -4 \\
Genistin & -7.3 & -8.7 & -7.4 & -6.6 & -8.2 & -8.5 & -2 \\
Naringenin & -8 & -8.1 & -7.7 & -6.5 & -8.9 & -9.1 & \\
Benzoic acid & -5.3 & -5.6 & -5.3 & -4.4 & -5.9 & -6 \\
Choline & -3.4 & -3.5 & -3.3 & -2.9 & -3.6 & -3.8 \\
\hline Vanllic acid & -5.3 & -5.6 & -5.3 & -4.5 & -6.2 & -6 \\
Quercitrin & -7.8 & -6.4 & -8.5 & -6.6 & -7.9 & -7 \\
Amentoflavone & -10.3 & -8.7 & -9.9 & -8.1 & -9.1 & -8.7 & \\
\hline Luteolin 7-galactoside & -9.3 & -8.2 & -8.7 & -7.1 & -9.4 & -8.8
\end{tabular}

Figure 7.

Docking results of key active components of A. bunius with target protein. Heat maps shows molecular docking binding energy less than $-7 \mathrm{~kJ} \cdot \mathrm{mol}-1$ in dark green color and above $-7 \mathrm{~kJ} \cdot \mathrm{mol}-1$ in dark blue color, respectively.

From the schematic diagram of the molecular docking 3D and hydrogen bonding (Figure 8), it can be seen that several major flavonoids of A. bunius bind to the amino acids in the docking pocket of the key target protein through hydrogen bonding. The binding energy of genistein and ESR1 protein is $-8.7 \mathrm{~kJ} \cdot \mathrm{mol}-1$ through asparagine (ASN-1705), glutamine (GLN-711) and arginine. Compared with several other key compounds of A. bunius, the binding energy of amentoflavone with AKT1, EGFR, and EP300 is the lowest, implying a strong binding. The chemical structures of luteolin and naringenin are very similar with only one hydroxyl difference on the B-benzene ring (Figure 9). The hydrogen bond sites of luteolin and ERBB2 are arginine, lysine and leucine. Naringenin and AR protein are combined with arginine, histidine (HIS-524) and phenylalanine (PHE-404). The docking results of flavonoids and organic acid compounds with the key target proteins further proved that the flavonoids in the fruit of A. bunius could be important functional components for inhibition of breast cancer growth.
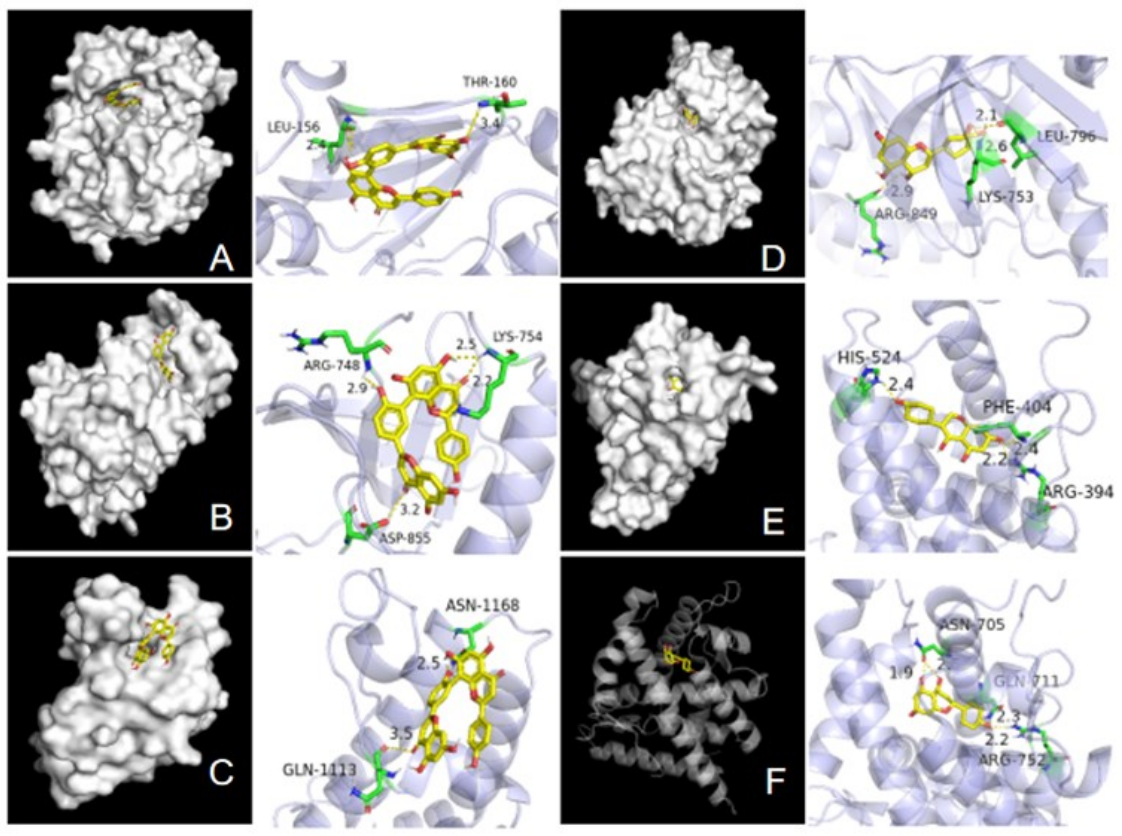

Figure 8.

Schematic diagrams of the docking and hydrogen bonding of active components of A. bunius with target protein A: amentoflavone-AKT1, B: amentoflavone-EGFR, C: amentoflavone-EP300, D: luteolin-ERBB, E: Naringenin-AR, F:Genistin-ESR1. 


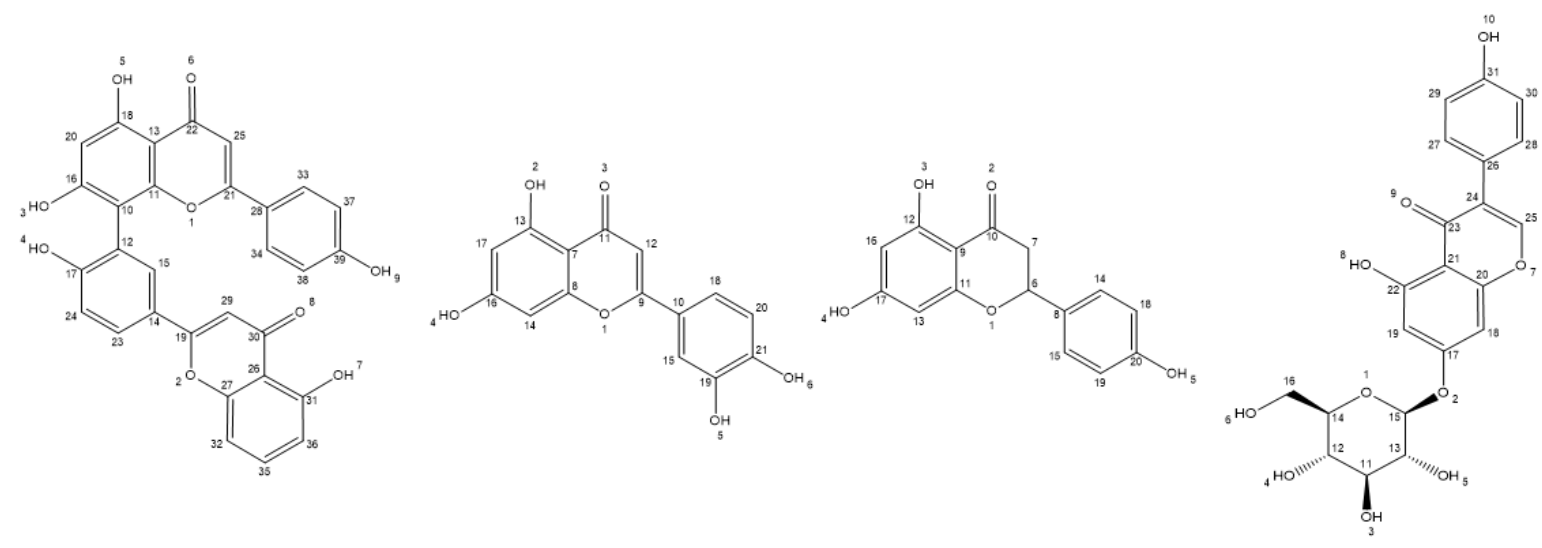

Amentoflavone

luteolin

Narigenin

Genistin

Figure 9.

The chemical structure of flavonoids present in the fruit of A.bunius.

\section{DISCUSSION}

From the network analysis of $A$. bunius fruit components and breast cancer targets, flavonoids and organic acid compounds were identified as the main functional substances. Organic acids are the main substances that make up the sourness of fruits, and flavonoids are the largest type of polyphenols, which are involved in the production of plant pigments, the regulation of hormone activity, and the resistance to biological and abiotic stresses. Flavonoids are also an important member of many medicinal active ingredients of plants, with anti-oxidation, antibacterial, antitumor, hypoglycemic and other medicinal biological activities (Russo et al., 2020). The fruit of $A$. bunius is rich in polyphenols and phenolic acid compounds, especially gallic acid, epicatechin pyrocatechin and cyanidin-3-O-glucoside (Butkhup \& Samappito, 2008). Previously, it has been reported that the crude methanol extract of leaves and fruits of $A$. bunius could effectively reduce the hatching rate of Artemia salina with significant cytotoxic activity (Micor et al., 2005). In addition, our group has reported that the fruit of A. bunius contains anti-proliferative compounds against breast cancer cells (Ma et al., 2020, 2021).

Amentoflavone is a kind of diflavonoids with a relatively high content in the total components of the fruit of A. bunius (Ma et al., 2020). Amentoflavone was first discovered from Selaginellae Moellendorfii (Pei et al., 2012), also discovered in Ginkgo Folium, Ginkgo Semen, Forsythiae Fructus, Platycladi Cacumen and other plants. Studies have shown that amentoflavone has anti-inflammatory, anti-viral, antioxidant, hypoglycemic and anti-tumor biological activities (Islam et al., 2018), also showed inhibitory activity on breast cancer cells (Cao et al., 2017). The oral bioavailability $(\mathrm{OB} \%)$ of amentoflavone is as low as 2.95 by checking the TCMSP website (Ru et al., 2014). Although amentoflavone is not included in the key functional ingredients of $A$. bunius in the present study, its various biological activities have been confirmed by other studies that deserve more attention.
AKT kinase (RAC- $\alpha$ serine/threonine-protein kinase) regulates cell metabolism, proliferation and angiogenesis through a series of downstream substrates' serine or threonine phosphorylation. AKT1 may play an anti-TNBC (triple negative breast cancer) effect by acting on the PI3K-Akt signaling pathway (Jiang et al., 2020). Hormone signaling is closely related to the occurrence and development of breast cancer. Estrogen receptor (ESR) is a nuclear receptor that is involved in regulating eukaryotic gene expression and affecting cell proliferation and differentiation in target tissues. There are two types of estrogen receptors: ESR1 and ESR2 are the main targets of luminal A breast cancer (Abula et al., 2019). Epidermal growth factor receptor (EGFR) and ERBB2 (HER2) are both cell membrane receptors. EGFR is over-expressed in a variety of malignant tumors. Activating EGFR will speed up tumor reproduction and metastasis. EGFR inhibitors can block signal transduction. Receptor tyrosine protein kinase erbB-2 (ERBB2) is a cell membrane receptor encoded by the proto-oncogene erbB-2. It belongs to the receptor tyrosine kinase family and is also a member of the EGFR family including HER1 HER2, HER3 and HER4 are the basic component of the neuregulin-receptor complex, which regulates the growth and stability of peripheral microtubules. The overexpression of EGFR and ERBB2 affects the ERK pathway and the PI3K-AKt pathway in HER2-positive and TNBC breast cancer (Park et al., 2020). Histone acetyltransferase $\mathrm{P} 300$ (EP300) is a nuclear receptor and a co-activator of HIF1A (hypoxia inducible factor $1 \alpha$ ). It mainly acts on the vascular endothelial growth factor (VEGF) signaling pathway affect vascular proliferation $(\mathrm{H}$. Li et al., 2020). Androgen receptor (AR) belongs to the steroid hormone receptor, which affects cell proliferation by interacting with the downstream prostate specific antigen PSA (prostate specific antigen) (Hickey et al., 2021). The flavonoids in the fruit of $A$. bunius have a strong combination with core targets such as AKT1, ESR1, EGFR, EP300, ERBB2, and AR, further verifying the anti-cancer activity of A. bunius.

In this study, network pharmacology and molecular 
ISSNe: 2617-9156

docking analysis were performed on the active ingredients of A. bunius fruit and the targets of breast cancer, and the main active ingredients and key targets were comprehensively screened. Flavonoids of $A$. bunius fruit could act on multiple relevant signaling pathways in breast cancer. Therefore, fruit of A. bunius has the potential for developing anti-cancer functional foods or nutraceuticals for adjuvant cancer treatment.

\section{ACKNOWLEDGEMENTS}

This study was financially sponsored by the Basal Research Fund of the Central Public-interest Scientific Institution of the Chinese Academy of Tropical Agricultural Sciences (grant number 1630092019002).

\section{REFERENCES}

[1] Abula, G., Ding, W., Li, D., Yan, X., Pei, X., \& Xu, H. (2019). Mechanism of Astragalus membranaceus Multicomponent synergistic therapy for breast cancer based on network pharmacology. Chemical and Biological Engineering, 10, 35-40.

[2] Butkhup, L., \& Samappito, S. (2008). An analysis on flavonoids contents in Mao Luang fruits of fifteen cultivars (Antidesma bunius), grown in northeast Thailand. Pakistan Journal of Biological Sciences: PJBS, 11(7), 996-1002. https://doi.org/10.3923/pjbs.2008.996.1002

[3] Cai, Y., Zeng, M., \& Chen, Y.-Z. (2021). The pharmacological mechanism of Huashi Baidu Formula for the treatment of COVID-19 by combined network pharmacology and molecular docking. Annals of Palliative Medicine, 10(4), 3864-3895. https://doi.org/10.21037/apm-20-1759

[4] Cao, Q., Qin, L., Huang, F., Wang, X., Yang, L., Shi, H., Wu, H., Zhang, B., Chen, Z., \& Wu, X. (2017). Amentoflavone protects dopaminergic neurons in MPTP-induced Parkinson's disease model mice through PI3K/Akt and ERK signaling pathways. Toxicology and Applied Pharmacology, 319, 80-90. https://doi.org/10.1016/j.taap.2017.01.019

[5] Dai, X. (2016). May Tea of Ming Dynasty in Jiaoyuan Village. Land Greening, 8, 43.

[6] Hickey, T. E., Dwyer, A. R., \& Tilley, W. D. (2021). Arming androgen receptors to oppose oncogenic estrogen receptor activity in breast cancer. British Journal of Cancer. https://doi.org/10.1038/s41416-02101478-8

[7] Islam, S., Ahammed, S., Sukorno, F. I., Koly, S. F., Biswas, M., \& Hossain, S. (2018). A review on phytochemical and pharmacological potentials of Antidesma bunius. Journal of Analytical \& Pharmaceutical Research, Volume 7(Issue 5), 602-604. https://doi.org/10.15406/japlr.2018.07.00289

[8] Jiang, M., Hu, Y., Lin, G., Chen, C., \& Li, H. (2020). Network Pharmacology and Bioinformatics-based Study on Mechanism of Resveratrol Against Triple Negative Breast Cancer. Chinese Journal of Modern Applied Pharmacology, 37(20), 2459-2464.

[9] Krongyut, O., \& Sutthanut, K. (2019). Phenolic Profile, Antioxidant Activity, and Anti-obesogenic Bioactivity of Mao Luang Fruits (Antidesma bunius L.). Molecules (Basel, Switzerland), 24(22), E4109. https://doi.org/10.3390/molecules24224109

[10] Li, B., \& Hoffmann, P. (2008). ANTIDESMA Burman ex Linnaeus, Sp. Pl. 2: 1027. 1753. Flora of China, 11, 209-215.

[11] Li, H., Zhao, B., Liu, Y., Deng, W., \& Zhang, Y. (2020). Angiogenesis in residual cancer and roles of HIF-1 $\alpha$, VEGF, and MMP-9 in the development of residual cancer after radiofrequency ablation and surgical resection in rabbits with liver cancer. Folia Morphologica, 79(1), 71-78 https://doi.org/10.5603/FM.a2019.0059

[12] Li, J. (1995). Composition preparation and clinical verification of Burn past. Guangxi Traditional Chinese Medicine, 6, 35 .

[13] Ma, F., Huang, D., Song, S., Wu, B., Guo, G., Wang, D., \& Tan, L. (2020). Inhibitory Activity of Extracts of Antidesma montanum on the Proliferation of Breast Cancer Cells MDA-MB-231. Chinese journal of tropical crops, 41(8), 1693-1699.

[14] Ma, F., Masood, T., Huang, D., Wu, B., Ge, Y., Chen, D., Gutierrez-Pajares, J. L., Nasiruddin, \& Song, S. (2021). Inhibitory Activity of Fruits Extracts of Antidesma bunius on the Proliferation and Migration of MDA-MB-231 Breast Cancer Cells. Journal of Food and Nutrition Research, 9(2), 61-67. https://doi.org/10.12691/jfnr-9-2-1

[15] Micor, J. R., Deocaris, C. C., \& Mojica, E.-R. E. (2005). Biological Activity of Bignay [Antidesma bunius (L.) Spreng] Crude Extract in Artemia salina. Journal of Medical Sciences, 5(3), 195-198.

[16] Park, J.-Y., Kang, S.-E., Ahn, K. S., Um, J.-Y., Yang, W. M., Yun, M., \& Lee, S.-G. (2020). Inhibition of the PI3K-AKT-mTOR pathway suppresses the adipocytemediated proliferation and migration of breast cancer cells. Journal of Cancer, 11(9), 2552-2559. https://doi.org/10.7150/jca.37975 
[17] Pei, J.-S., Liu, C.-C., Hsu, Y.-N., Lin, L.-L., Wang, S.C., Chung, J.-G., Bau, D.-T., \& Lin, S.-S. (2012). Amentoflavone induces cell-cycle arrest and apoptosis in MCF-7 human breast cancer cells via mitochondriadependent pathway. In Vivo (Athens, Greece), 26(6), 963-970.

[18] Ru, J., Li, P., Wang, J., Zhou, W., Li, B., Huang, C., Li, P., Guo, Z., Tao, W., Yang, Y., Xu, X., Li, Y., Wang, Y., \& Yang, L. (2014). TCMSP: A database of systems pharmacology for drug discovery from herbal medicines. Journal of Cheminformatics, 6, 13. https://doi.org/10.1186/1758-2946-6-13

[19] Russo, M., Moccia, S., Spagnuolo, C., Tedesco, I., \& Russo, G. L. (2020). Roles of flavonoids against coronavirus infection. Chemico-Biological Interactions, 328, 109211. https://doi.org/10.1016/j.cbi.2020.109211

[20] Shanghai Science and Technology Press. (1999). May Tea 【Chinese Medicinal Materials Collection】 Chinese Medicine Collection. http://www.zhongyaocai360.com/w/wuyuecha.html\#2 8325

[21] Wei, Gao. (2015). Study on the chemical constituents of Dendrobium gratiosissmum and Antidesma bunius [ 硕 士, Anhui University of Traditional Chinese Medicine]. https://global.cnki.net/kcms/detail/detail.aspx?filename $=1015361736 . n$ h $\&$ dbcode $=$ CMFD\&dbname $=$ CMFD20 $16 \& \mathrm{v}=$

[22] Zhaohui, A. (2011). Preliminary study on chemical components of Antidesma montanum. China Medical Herald, 8(13), 37-38. 